\title{
Circadian Variation in Gastric Vagal Afferent Mechanosensitivity
}

\author{
Stephen J. Kentish, ${ }^{1}$ Claudine L. Frisby, ${ }^{3}$ David J. Kennaway, ${ }^{2}$ Gary A. Wittert, ${ }^{1}$ and Amanda J. Page ${ }^{1,3}$ \\ ${ }^{1}$ Discipline of Medicine, University of Adelaide, Adelaide, South Australia, Australia 5005, ${ }^{2}$ Robinson Institute, School of Paediatrics and Reproductive \\ Health, University of Adelaide, Adelaide, 5005, and ${ }^{3}$ Royal Adelaide Hospital, Adelaide, South Australia, Australia 5000
}

Food intake is coordinated to cellular metabolism by clock gene expression with a master clock in the suprachiasmatic nucleus synchronized by light exposure. Gastric vagal afferents play a role in regulating food intake, but it is unknown whether they exhibit circadian variation in their mechanosensitivity. We aimed to determine whether gastric vagal afferents express clock genes and whether their response to mechanical stimuli oscillates throughout the light/dark cycle. Nodose ganglia were collected from 8-week-old female C57BL/6 mice every $3 \mathrm{~h}$ starting at lights off $(1800 \mathrm{~h})$ to quantify Bmal1, Per1, Per2, and Nr1d1 mRNA by qRT-PCR. Additionally in vitro single-fiber recordings of gastric vagal mechanoreceptors were taken at all time points. Per1, Per2, Bmal1, and Nr1d1 mRNA is expressed in the nodose ganglia and levels oscillated over a $24 \mathrm{~h}$ period. In mice fed ad libitum, gastric content was 3 times higher at $0000 \mathrm{~h}$ and $0300 \mathrm{~h}$ than $1200 \mathrm{~h}$. The response of tension receptors to $3 \mathrm{~g}$ stretch was reduced by up to $70 \%$ at $2100 \mathrm{~h}, 0000 \mathrm{~h}$, and $0300 \mathrm{~h}$ compared with $1200 \mathrm{~h}$. Gastric mucosal receptor response to stroking with a $50 \mathrm{mg}$ von Frey hair was 3 times greater at $1200 \mathrm{~h}$ and $1500 \mathrm{~h}$ than the response at $0000 \mathrm{~h}$. Similar findings were obtained in mice fasted for $6 \mathrm{~h}$ or maintained in darkness for $3 \mathrm{~d}$ before study. Therefore, these changes do not result from food intake or the light/dark cycle. Thus, gastric vagal mechanoreceptors display circadian rhythm, which may act to control food intake differentially at different times of the day.

\section{Introduction}

Most physiological processes, including food intake, vary in a circadian manner coordinated by cellular clocks entrained to a central clock, located in the suprachiasmatic nucleus (SCN), which in turn is entrained by the prevailing photoperiod (Ueyama et al., 1999). The SCN uses a transcriptional-translational feedback loop of genes, including Clock, Bmal1, Per1, Per2, and Nr1d1, to create a molecular clock (Bass and Takahashi, 2010). The circadian timing system is hierarchical, with the SCN informing the rest of the body of the photoperiod via neural and hormonal pathways (Dibner et al., 2010). The same clock genes are expressed in peripheral tissues, including the stomach and colonic epithelium (Hoogerwerf et al., 2007; Konturek et al., 2011). This suggests that peripheral tissue may be able to act independently of the SCN to mediate local function in a clocklike manner. This notion is supported by liver and lung tissue explants exhibiting circadian oscillations in clock gene expression after disconnection from the SCN (Yoo et al., 2004).

Like most physiological processes, food intake is highly regulated and shows strong circadian patterns, with mice consuming

\footnotetext{
Received Sept. 9, 2013; revised 0ct. 29, 2013; accepted 0ct. 29, 2013.

Author contributions: S.J.K., D.J.K., G.A.W., and A.J.P. designed research; S.J.K., C.L.F., and A.J.P. performed research; D.J.K. contributed unpublished reagents/analytic tools; S.J.K. and A.J.P. analyzed data; S.J.K., G.A.W., and A.J.P. wrote the paper.

This work was supported by National Health and Medical Research Council Grant 1046289.

The authors declare no competing financial interests.

Correspondence should be addressed to Dr. Amanda J. Page, University of Adelaide, Discipline of Medicine, Level 6 Eleanor Harrald Building, Frome Road, Adelaide, South Australia 5005, Australia. E-mail: Amanda.page@adelaide.edu.au.

DOI:10.1523/JNEUROSCI.3846-13.2013

Copyright $\odot 2013$ the authors $\quad 0270-6474 / 13 / 3319238-05 \$ 15.00 / 0$
}

the majority of their daily food within the active dark phase (Pendergast et al., 2013). Although the SCN can influence and drive eating behavior (Coomans et al., 2013a), it is likely that there is another source of circadian drive as SCN-lesioned rats are still entrainable to a feeding schedule (Stephan et al., 1979). Food intake is regulated by a variety of mechanisms, including gastric vagal afferents (Schwartz, 2000), and these have been implicated in the signaling of satiety as well as mediating gastric motor activity (Schwartz, 2000).

Within the stomach wall, there are two classes of mechanically sensitive gastric vagal afferents. In the muscular layer, tension receptors detect fullness by responding to distension and contraction of the stomach wall (Blackshaw et al., 1987; Wang et al., 2008). In contrast, mucosal receptors are excited by mechanical contact of larger food particles with the epithelium and may contribute to the discrimination of particle size. The net effect of activating mucosal afferents is to trigger vagal reflexes that slow gastric emptying and facilitate mechanical digestion in the stomach (Becker and Kelly, 1983). Previously, we have shown that the mechanosensitivity of gastric vagal afferents is not a static trait with leptin and ghrelin exerting potentiating and inhibitory effects on vagal afferent mechanosensitivity, respectively (Kentish et al., 2012; 2013b). It is unclear, however, whether vagal afferent mechanosensitivity is under the control of peripherally located cellular clocks.

We sought to determine whether (1) there is clock gene expression within the nodose ganglia, where the cell bodies of vagal afferents are located, and (2) whether gastric vagal afferents exhibited circadian variation, which may play a role in regulating the amount of food that can be consumed before satiation is reached. 

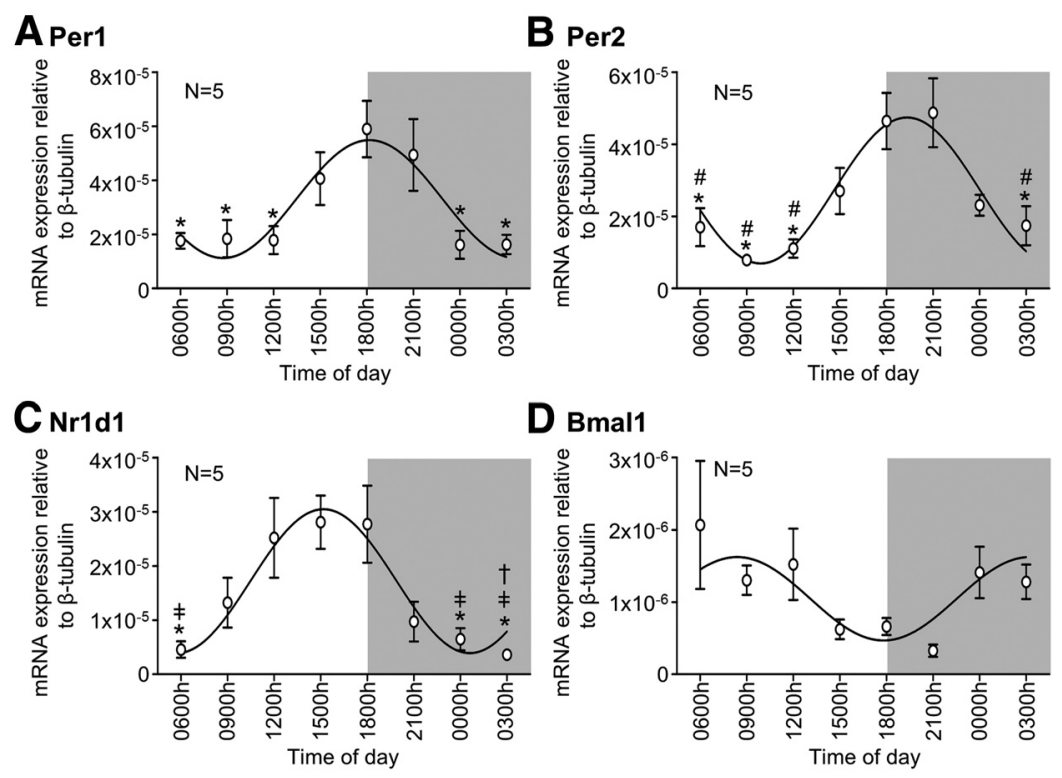

Figure 1. Nodose ganglia expression of clock genes. qRT-PCR results showing the relative $\operatorname{Per1}(\boldsymbol{A}), \operatorname{Per} 2(\boldsymbol{B}), \operatorname{Nr} 1 d 1(\boldsymbol{C})$, and Bmal1 (D) mRNA content of the nodose ganglia from mice $(N=5 /$ time point) fed ad libitum and housed under $12: 12 \mathrm{~h} \mathrm{light} / \mathrm{dark}$ cycle at various times of the day. Data are mean \pm SEM. $\dagger p<0.05$ vs $1200 \mathrm{~h}$. $\neq p<0.05$ vs $1500 \mathrm{~h} .{ }^{*} p<0.05$ vs $1800 \mathrm{~h}$. $\# p<0.05$ vs $2100 \mathrm{~h}$.

\section{Materials and Methods}

Ethical approval. All studies were approved and performed in accordance with the guidelines of the Animal Ethics Committees of the University of Adelaide and SA Pathology, Adelaide, Australia.

Mice. Female C57BL/6 mice, 7 weeks of age, were housed with littermates for 1 week before experimentation. Unless otherwise mentioned, all mice were housed under a 12:12 h light/dark cycle, with lights on at 0600 and off at $1800 \mathrm{~h}$ and had free access to food and water. One group of mice $(N=40)$ were allowed ad libitum access to food and water up until the time of study, which was undertaken every $3 \mathrm{~h}$ commencing at $0600 \mathrm{~h}$ ( $N=5$ /time point). A second group $(N=20)$ had free access to water but were deprived of food for the $6 \mathrm{~h}$ before study, to remove any influence that the presence of food may have on the stomach, and studied at $1200 \mathrm{~h}$, $1500 \mathrm{~h}, 0000 \mathrm{~h}$, and $0300 \mathrm{~h}(N=5$ /time point $)$. These time points were chosen as they were time points of peak and nadir stomach food content in mice fed ad libitum. A third group $(N=40)$ were housed in continuous darkness for $72 \mathrm{~h}$ before study at $3 \mathrm{~h}$ intervals starting at $0600 \mathrm{~h}(\mathrm{~N}=$ $5 /$ time point).

In vitro mouse gastroesophageal afferent preparation. This preparation has been described in detail previously (Page et al., 2002). In short, $\mathrm{C} 57 \mathrm{BL} / 6$ mice were killed via $\mathrm{CO}_{2}$ inhalation and the thorax opened by a midline incision. After removal, with vagal nerves attached, the stomach and esophagus were opened out longitudinally and pinned down mucosa side up in an organ bath containing a modified Krebs solution composing of (in mM) as follows: $118.1 \mathrm{NaCl}, 4.7 \mathrm{KCl}, 25.1 \mathrm{NaHCO}_{3}, 1.3$ $\mathrm{NaH}_{2} \mathrm{PO}_{4}, 1.2 \mathrm{MgSO}_{4} .7 \mathrm{H}_{2} \mathrm{O}, 1.5 \mathrm{CaCl}_{2}, 1.0$ citric acid, 11.1 glucose, and 0.001 nifedipine, bubbled with $95 \% \mathrm{O}_{2} 5 \% \mathrm{CO}_{2}$. The dissection process was performed at $4^{\circ} \mathrm{C}$ to prevent metabolic breakdown.

Characterization of gastric vagal afferent properties. The process used to identify mouse gastroesophageal mechanosensitive vagal afferents has been described in detail previously (Kentish et al., 2013c). Briefly, mucosal receptors respond to mucosal stroking, but not to circular tension and tension receptors respond to both mucosal stroking and circular tension. Receptive fields of these receptors in the esophagus and stomach were first located using mechanical stimulation with a brush. Once located, specific stimuli were then applied. Mucosal stroking was performed using a calibrated von Frey hair $(50 \mathrm{mg})$, which was stroked across the mucosa at a rate of $5 \mathrm{mms}^{-1}$. Each receptive field was stroked 10 times and mechanical responses from the middle eight strokes taken for analysis. Circular tension was applied using a threaded hook attached to an underpinned point adjacent to the receptive field. The hook was attached to a cantilever via a pulley close to the preparation. A 3 g weight was then placed on the opposite end of the cantilever for a period of $1 \mathrm{~min}$. After analyzing the response to the two stimuli, we would classify a receptive field as either a mucosal or tension receptor.

Single-unit vagal afferent recordings. Single units, from both left and right vagal nerves, were discriminated on the basis of action potential shape, duration, and amplitude using Spike 2 software (Cambridge Electronic Design).

Nodose ganglia $q R T-P C R$. Nodose ganglia were removed bilaterally from the $12: 12 \mathrm{~h}$ light/dark cycle fed ad libitum mice at all 8 time points. Total RNA was extracted from both left and right nodose ganglia combined using an RNeasy Micro Kit (QIAGEN) according to the manufacturer's instructions. RNA was quantified by measuring absorbance at $260 \mathrm{~nm}$ (A260) using a NanoDrop ND 1000 spectrophotometer (Thermo Fisher Scientific). qRTPCR reactions were performed as described previously (Kentish et al., 2013a). The primer targeting $\beta$-tubulin was a predesigned Quantitect Primer assay (QIAGEN). The primers for Bmal1, Per1, Per2, and Nr1d1 were designed using Primer Express (Applied Biosystems) and manufactured by GeneWorks. Their sequences were as detailed previously (Kennaway et al., 2006): Bmal1 forward, GTCGAATGATTGCCGAGGAA; reverse, GGGAGGCGTACTTGTGATGTTC; Perl forward, TTTGGAGAGCTGCAACATTCC; reverse, TGCTGACGACGGARTCTTTCTTG; Per2 forward, AGGCACCTCCAACATGCAA; reverse, GGATGCCCCGCTT CTAGAC; Nrld1 forward, TCCAGTACAAACGGTGTCTGAAA; reverse, GCCAACGGAGAGACACTTCTTG. A melt curve was obtained to confirm specificity of the products produced. Relative RNA levels were calculated using the comparative $\mathrm{C}_{\mathrm{T}}$ method as described previously (Pfaffl et al., 2002), with $\beta$-tubulin as the normalizer. The $\mathrm{C}_{\mathrm{T}}$ values of $\beta$-tubulin did not vary over a $24 \mathrm{~h}$ period.

Statistical analysis. All data are expressed as mean \pm SEM with $N=$ the number of individual animals used. The response to mechanical stimuli, stomach contents, and qRT-PCR results at different times of the day were analyzed using a one-way ANOVA with Tukey's post hoc test. The correlation between the stomach contents and vagal afferent mechanosensitivity was analyzed by linear regression analysis.

\section{Results}

\section{Clock gene expression in the nodose ganglia}

All four clock genes studied were present in the nodose ganglia at all 8 time points. Perl mRNA content varied throughout the day $\left(F_{(7.32)}=4.86, p<0.001\right.$, one-way ANOVA $)$, peaking at $1800 \mathrm{~h}$ before reducing at $0000 \mathrm{~h}$ through to $1200 \mathrm{~h}$ (all $p<0.05$ vs 1800 h; Tukey post hoc; Fig. 1A). Per 2 mRNA also varied throughout the day $\left(F_{(7,32)}=6.84, p<0.001\right.$, one-way ANOVA $)$ with an elevation at $1800 \mathrm{~h}$ and $2100 \mathrm{~h}$. Thereafter, Per 2 mRNA content was significantly lower from $0300 \mathrm{~h}$ through to $1200 \mathrm{~h}$ (all $p<$ $0.05 \mathrm{vs} 1800 \mathrm{~h}$ and $2100 \mathrm{~h}$; Tukey post hoc; Fig. 1B). Nr1d 1 mRNA exhibited significant variation in level throughout the light/dark cycle $\left(F_{(7,32)}=5.21, p<0.001\right.$, one-way ANOVA), with elevated levels observed at $1200 \mathrm{~h}, 1500 \mathrm{~h}$, and $1800 \mathrm{~h}$ and nadir at $0000 \mathrm{~h}$ $(p<0.05$ vs $1500 \mathrm{~h}$ and $1800 \mathrm{~h}$; Tukey post hoc), $0300 \mathrm{~h}(p<0.05$ vs $1200 \mathrm{~h}, 1500 \mathrm{~h}$, and $1800 \mathrm{~h}$; Tukey post hoc), and $0600 \mathrm{~h}(p<$ $0.05 \mathrm{vs} 1500 \mathrm{~h}$ and $1800 \mathrm{~h}$; Tukey post hoc; Fig. 1C). Bmall mRNA content was more variable such that the ANOVA did not reach significance $\left(F_{(7,32)}=1.81, p>0.05\right.$, one-way ANOVA; Fig. $\left.1 D\right)$; 
however, the lowest level of expression occurred at $2100 \mathrm{~h}, \sim 12 \mathrm{~h}$ before the peak expression of the other genes.

\section{Daily variation in gastric vagal mechanosensitivity}

The amount of food present in the stomach varied throughout the light/dark cycle $\left(F_{(7,32)}=30.12, p<0.001\right.$, one-way ANOVA), with $>12$ times more food present at $0000 \mathrm{~h}$ and $0300 \mathrm{~h}$ relative to 1200 h (both $p<0.001$ vs 1200 h; Tukey post hoc). Gastric tension receptor mechanosensitivity increased through the light phase and then decreased during the dark phase $\left(F_{(7,32)}=24.91, p<0.001\right.$, one-way ANOVA; Fig. 2A). There was a $50 \%$ reduction in response to $3 \mathrm{~g}$ tension at $2100 \mathrm{~h}$ ( $p<0.001$ vs $1200 \mathrm{~h}$; Tukey post $h o c)$, which was further reduced to a $72 \%$ and $74 \%$ reduction at $0000 \mathrm{~h}$ and $0300 \mathrm{~h}$, respectively ( $p<0.001$ vs $1200 \mathrm{~h}$; Tukey post hoc). Gastric mucosal receptors similarly exhibited variation in their responsiveness to mechanical stimulation $\left(F_{(7,32)}=\right.$ 5.69, $p<0.001$, one-way ANOVA; Fig. $2 B$ ) with the response to mucosal stroking with a $50 \mathrm{mg}$ von Frey hair reduced by $51 \%$ at $2100 \mathrm{~h}$ ( $p<0.05$ vs $1200 \mathrm{~h}$; Tukey post hoc), $71 \%$ at $0000 \mathrm{~h}(p<0.01$ vs $1200 \mathrm{~h}$; Tukey post hoc), and 70\% at $0300 \mathrm{~h}$ ( $p<0.01$ vs $1200 \mathrm{~h}$; Tukey post hoc). When the responsiveness of gastric tension receptors and mucosal receptors was plotted against the stomach content (Fig. 2C,D), there was a significant negative correlation between the afferent responsiveness and the stomach content with $R$ values of -0.85 and -0.59 , respectively (linear regression analysis, both $p<0.0001$ ). The recordings taken from esophageal receptors revealed no significant variation in responsiveness of either type of afferents throughout the light/dark cycle and no relationship with the amount of food in the stomach (tension receptors: $F_{(7,28)}=0.39, p<0.001$, one-way ANOVA; Fig. 2E; and mucosal receptors: $F_{(7,31)}=0.0 .60, p<0.001$, one-way ANOVA; Figure $2 F$ ).

\section{Gastric mechanosensitivity variation} after acute food restriction

After a $6 \mathrm{~h}$ fast, there was very little gastric content at any time point $\left(F_{(3,16)}=1.66\right.$, $p>0.05$, one-way ANOVA; Fig. $3 A$ ). However, there was still variation in the response of tension receptors to $3 \mathrm{~g}$ circular stretch in mice that had been fasted $\left(F_{(3,16)}=6.96\right.$, $p<0.01$, one-way ANOVA) with the response reduced by $61 \%$ at $0000 \mathrm{~h}$ and $70 \%$ at $0300 \mathrm{~h}$ compared with $1200 \mathrm{~h}(p<0.05$ and $p<0.01$, respectively; Tukey post hoc; Fig. 3A). Similarly, mucosal receptor re-
A Gastric Tension

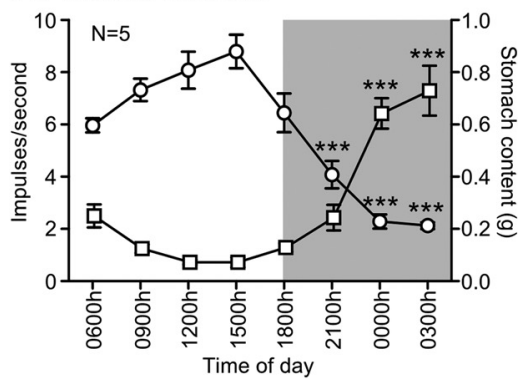

O Response to $3 \mathrm{~g}$ tension

C Gastric Tension

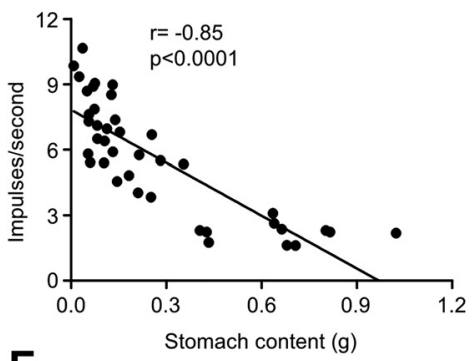

E Oesophageal Tension

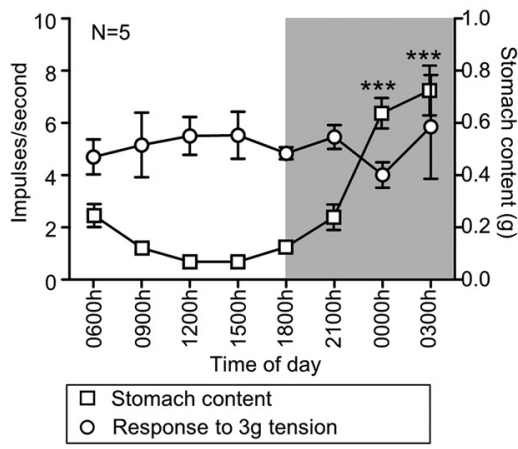

$\square$ Stomach content
B Gastric Mucosal

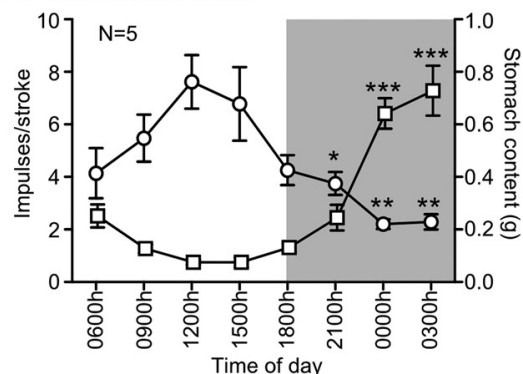

$\square$ Stomach content

O Response to $50 \mathrm{mg}$ von Frey hair

\section{Gastric Mucosal}

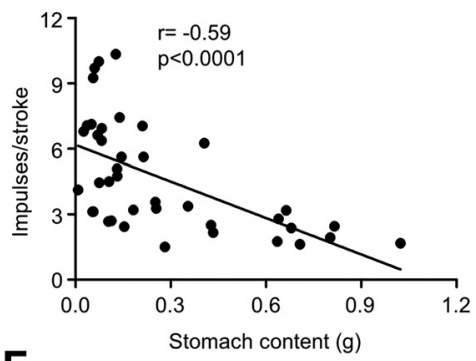

F Oesophageal Mucosal

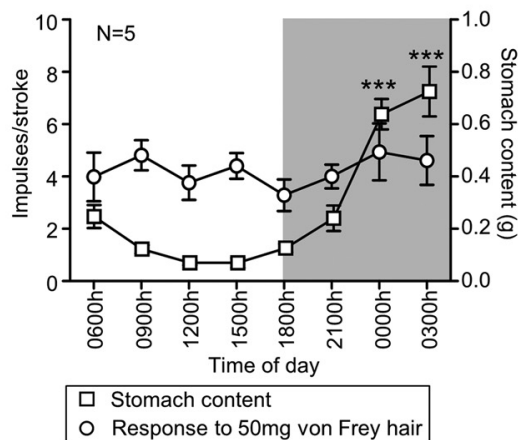

Figure 2. Circadian variation in gastric vagal afferent mechanosensitivity. Response of gastric tension receptors $(N=5 /$ time point) to $3 \mathrm{~g}$ tension $(\boldsymbol{A} ; \bigcirc)$ and mucosal receptors $(N=5 /$ time point) to mucosal stroking with a $50 \mathrm{mg}$ von Frey hair $(\boldsymbol{B} ; \bigcirc)$ exhibited a negative relationship with the amount of food in the stomach $(\square)$ during both the light and dark (shaded) phases. $C$, $D$, Scatter plots demonstrating the negative correlation between sensitivity of tension and mucosal receptors and stomach content, respectively. No variation in response to tension $(\boldsymbol{E} ; O)$ or mucosal stroking $(\boldsymbol{F} ; O)$ and no relationship to stomach content $(\square)$ was observed in esophageal tension $(\boldsymbol{E} ; N=5 /$ time point $)$ and mucosal receptors $(\boldsymbol{F} ; N=5 /$ time point $)$. Data are mean \pm SEM. ${ }^{*} p<0.05$ vs $1200 \mathrm{~h} .{ }^{* *} p<0.01$ vs $1200 \mathrm{~h} .{ }^{* * *} p<0.001$ vs $1200 \mathrm{~h}$.
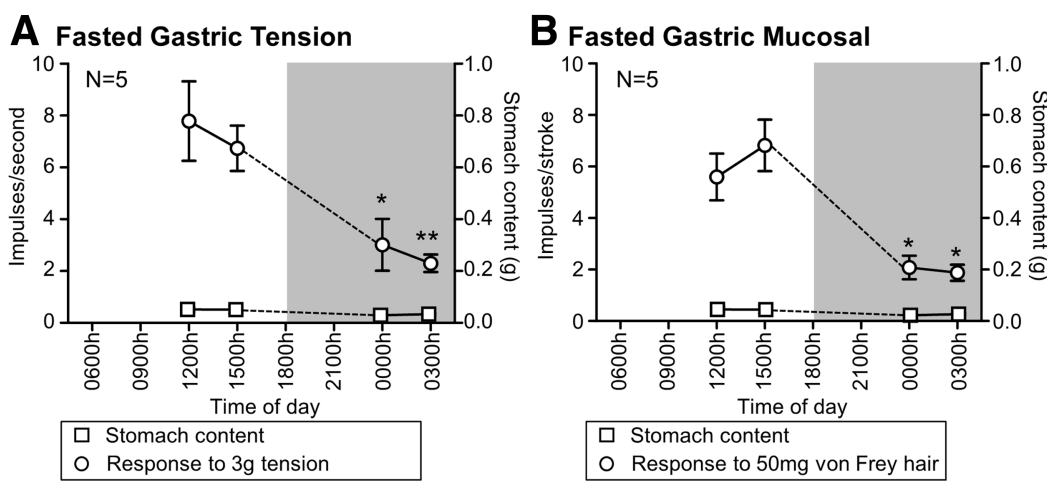

Figure 3. Circadian variation in gastric vagal afferent mechanosensitivity is not dependent on food. Response of gastric tension receptors $(N=5 /$ time point) to $3 \mathrm{~g}$ tension $(\boldsymbol{A} ; \bigcirc)$ and mucosal receptors $(N=5 /$ time point $)$ to mucosal stroking with a $50 \mathrm{mg}$ von Frey hair $(\boldsymbol{B} ; \bigcirc)$. Stomach content $(\square)$ was consistently low during both the light and dark (shaded) phase. Data are mean $\pm \mathrm{SEM}$. ${ }^{*} p<0.05$ vs $1200 \mathrm{~h}$. ${ }^{* *} p<0.01$ vs $1200 \mathrm{~h}$. 
A Darkness Gastric Tension
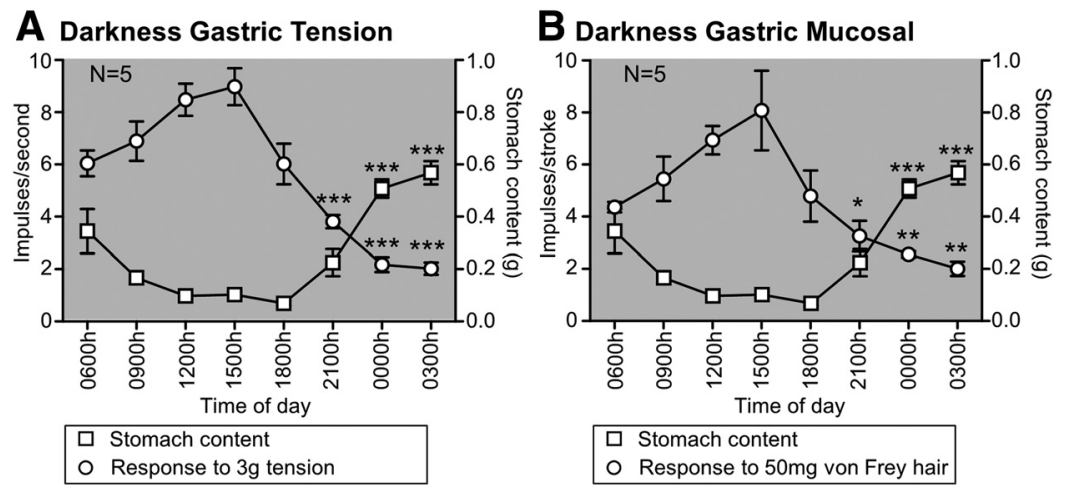

Figure 4. Circadian variation in gastric vagal afferent mechanosensitivity occurs independent of acute exposure to light. Response of gastric tension receptors $(N=5 /$ time point) to $3 \mathrm{~g}$ tension $(\boldsymbol{A} ; \bigcirc)$ and mucosal receptors $(N=5 /$ time point) to mucosal stroking with a $50 \mathrm{mg}$ von Frey hair $(\boldsymbol{B} ; O)$ after housing in total darkness for $72 \mathrm{~h}$. The inverse relationship between gastric afferent mechanosensitivity and the amount of food in the stomach $(\square)$ was maintained after being housed in darkness for $72 \mathrm{~h}$. Data are mean \pm SEM. ${ }^{*} p<0.05$ vs $1200 \mathrm{~h} .{ }^{* *} p<0.01$ vs $1200 \mathrm{~h} .{ }^{* * *} p<0.001$ vs $1200 \mathrm{~h}$.

sponse to stroking with a $50 \mathrm{mg}$ von Frey hair varied in fasted mice $\left(F_{(3,16)}=11.72, p<0.001\right.$, one-way ANOVA $)$ with a $63 \%$ reduction at $0000 \mathrm{~h}$ and $67 \%$ reduction at $0300 \mathrm{~h}$ relative to $1200 \mathrm{~h}$ (both $p<$ 0.05; Tukey post hoc; Fig. 3B).

\section{Gastric mechanosensitivity variation after $72 \mathrm{~h}$ constant darkness}

Mice that were housed in constant darkness had varying levels of gastric content throughout the day $\left(F_{(7,32)}=21.18, p<0.001\right.$, one-way ANOVA). The gastric contents of mice housed in constant darkness was at least 5 times greater at $0000 \mathrm{~h}$ and $0300 \mathrm{~h}$ relative to $1200 \mathrm{~h}$ (both $p<0.001 \mathrm{vs} 1200 \mathrm{~h}$; Tukey post hoc; Fig. $4 A, B)$. A similar variation occurred regardless of whether the mice were housed in constant darkness for $3 \mathrm{~d}$ or on a $12: 12 \mathrm{~h}$ light/dark cycle $\left(F_{(1,7)}=0.48, p>0.05\right.$, two-way ANOVA). The response of tension receptors to $3 \mathrm{~g}$ circular stretch varied in a circadian manner $\left(F_{(7,32)}=22.61, p<0.001\right.$, one-way ANOVA; Fig. $\left.4 A\right)$, reduced by $55 \%$ at $2100 \mathrm{~h}, 74 \%$ at $0000 \mathrm{~h}$, and $76 \%$ at $0300 \mathrm{~h}$ relative to $1200 \mathrm{~h}$ (all $p<0.001$ vs $1200 \mathrm{~h}$; Tukey post hoc). The level of oscillation in response to $3 \mathrm{~g}$ circular stretch observed in the mice that had been housed in darkness was not significantly different from that observed in ad libitum fed mice housed under 12:12 h light/dark $\operatorname{cycle}\left(F_{(1,7)}=0.10, p>0.05\right.$, two-way ANOVA).

Gastric mucosal mechanosensitivity also exhibited variation in mice that had been housed in constant darkness for $72 \mathrm{~h}\left(F_{(7,32)}=\right.$ $7.36, p<0.001$, one-way ANOVA; Fig. $4 B)$ with a $53 \%$ reduction at $2100 \mathrm{~h}$ ( $p<0.05$ vs $1200 \mathrm{~h}$; Tukey post hoc), a 63\% reduction at $0000 \mathrm{~h}$ ( $p<0.01$ vs $1200 \mathrm{~h}$; Tukey post hoc), and a $71 \%$ reduction at $0300 \mathrm{~h}$ ( $p<0.01$ vs $1200 \mathrm{~h}$; Tukey post hoc). There was no difference in the oscillation of mucosal receptor responses to stroking with a 50 mg von Frey hair between the mice housed in constant darkness for $3 \mathrm{~d}$ and mice housed under a 12:12 h light/dark cycle $\left(F_{(1,7)}=0.08\right.$, $p>0.05$, two-way ANOVA).

\section{Discussion}

We have demonstrated, for the first time, the expression of clock genes within vagal afferent cell bodies located in the nodose, that gastric mechanosensitive vagal afferents have different sensitivity to mechanical stimulation based on the time of day and that there is a strong negative relationship between gastric contents and the response to mechanical stimulation.

Although neuronal expression of clock genes is well established centrally in regions such as the SCN, the identification of clock genes in the nodose ganglia is the first evidence to suggest that vagal afferents may act as a peripheral clock. Peripheral neuronal clocks have been identified previously. For example, a similar pattern of circadian expression of Bmal1, Per1, and Per 2 has been detected in the spinal cord (Morioka et al., 2012). There is also clock gene expression within the myenteric plexus as well as the stomach and colonic epithelium (Hoogerwerf et al., 2007), suggesting that the gastrointestinal tract is capable of mediating its own function in a circadian manner. It has been demonstrated that cellular circadian pacemaking can modulate an array of signaling systems, including $\mathrm{Ca}^{2+}$, cAMP, cGMP, and nitric oxide (Golombek et al., 2004; Hastings et al., 2008), all of which could influence gastric vagal afferent mechanosensitivity, resulting in the observed circadian variation in response to mechanical stimuli.

The importance of vagal afferents in controlling feeding is well established (Schwartz, 2000). It is also established that the timing of food intake is important in maintaining a healthy metabolic state. This is well demonstrated in mice who consume food during the light phase exhibiting increased body weight (Arble et al., 2009; Bray et al., 2013). The finding that mechanosensitivity of gastric mechanoreceptors varies throughout the day, but is not dependent on food intake, suggests that the variation in mechanosensitivity may act to limit food consumption during the light phase when there is little need for energy and promote food consumption during the active dark phase.

Meal size in rodents varies dramatically between the light phase and dark phase with both increased frequency and size being reported in rats during the dark phase (Rosenwasser et al., 1981). The finding that gastric mechanosensitivity is reduced during the dark phase provides a potential mechanism to allow this to occur as activation of gastric tension receptors by distension of the stomach has been shown to induce satiety (Wang et al., 2008). Therefore, reduced response to distension during the dark phase would allow for more food to be consumed before satiation is reached. This is consistent with the observed increase in stomach content when mechanosensitivity is low. However, vagal afferents are involved in other functions, including gastric slowwave activity (Krolczyk et al., 2001; Liu et al., 2004) and gastric emptying (Krolczyk et al., 2001), both of which exhibit circadian variation in their levels (Trout et al., 1991; Aviv et al., 2008). Therefore, the oscillation in gastric mechanosensitivity may be involved in the circadian rhythm of other vagally mediated processes.

Although we have shown that the oscillation in gastric vagal mechanosensitivity does not require a light/dark cycle to occur and that vagal afferents express clock genes, we cannot conclude whether this phenomenon is actually being caused by a selfcontained clock or through descending input from the SCN. It has been shown that, after $72 \mathrm{~h}$ of constant darkness, circadian oscillations in SCN activity are maintained; however, this variation is attenuated under constant light conditions (Coomans et al., 2013b). Thus, it is possible that descending SCN signals may still regulate gastric vagal afferent mechanosensitivity. Alternatively, SCN activity has been shown to not be a consistently reliable marker for peripheral circadian rhythms. Intestinal clock 
gene rhythms have been observed to phase shift in response to timed food presentation, independent of the SCN (Hoogerwerf et al., 2007), suggesting the presence of a food entrained rhythm regulating peripheral clocks independent of the SCN. To conclusively determine the level of involvement of the SCN in the oscillation of gastric vagal afferent mechanosensitivity, further experiments that isolate or lesion the SCN need to be performed. In addition, experiments pairing food restriction with disruption of the normal light/dark cycle would provide further evidence for a vagal afferent clock driving mechanosensitivity.

Ovarian steroids have been shown to have effects on the timing of clock gene expression in SCN neurons (Shinohara et al., 2001). Estrogen receptor- $\alpha$ and $-\beta$ immunoreactivity and mRNA have been demonstrated in a subset of vagal afferent cell bodies within the nodose ganglia (Papka et al., 2001). Therefore, in the current study, it is possible that the estrous cycle could be having an effect on the timing of clock gene expression and the mechanosensitivity of gastric vagal afferents. This requires further investigation.

Thus, although it still remains to be determined whether the variation in mechanosensitivity is primarily driven by a vagal afferent clock or the SCN, we do report, for the first time, that there are clock genes expressed in the nodose ganglia and that gastric vagal afferents exhibit a circadian rhythm in response to mechanical stimulation, which perseveres in the acute absence of food and light, suggesting the possibility of a peripheral neural clock.

\section{References}

Arble DM, Bass J, Laposky AD, Vitaterna MH, Turek FW (2009) Circadian timing of food intake contributes to weight gain. Obesity 17:2100-2102. CrossRef Medline

Aviv R, Policker S, Brody F, Bitton O, Haddad W, Kliger A, Sanmiguel CP, Soffer EE (2008) Circadian patterns of gastric electrical and mechanical activity in dogs. Neurogastroenterol Motil 20:63-68. CrossRef Medline

Bass J, Takahashi JS (2010) Circadian integration of metabolism and energetics. Science 330:1349-1354. CrossRef Medline

Becker JM, Kelly KA (1983) Antral control of canine gastric emptying of solids. Am J Physiol Gastrointest Liver Physiol 8:334-338. Medline

Blackshaw LA, Grundy D, Scratcherd T (1987) Vagal afferent discharge from gastric mechanoreceptors during contraction and relaxation of the ferret corpus. J Auton Nerv Syst 18:19-24. CrossRef Medline

Bray MS, Ratcliffe WF, Grenett MH, Brewer RA, Gamble KL, Young ME (2013) Quantitative analysis of light-phase restricted feeding reveals metabolic dyssynchrony in mice. Int J Obes 37:843-852. CrossRef Medline

Coomans CP, van den Berg SA, Lucassen EA, Houben T, Pronk AC, van der Spek RD, Kalsbeek A, Biermasz NR, Willems van Dijk K, Romijn JA, Meijer JH (2013a) The suprachiasmatic nucleus controls circadian energy metabolism and hepatic insulin sensitivity. Diabetes 62:1102-1108. CrossRef Medline

Coomans CP, van den Berg SA, Houben T, van Klinken JB, van den Berg R, Pronk AC, Havekes LM, Romijn JA, van Dijk KW, Biermasz NR, Meijer JH (2013b) Detrimental effects of constant light exposure and high-fat diet on circadian energy metabolism and insulin sensitivity. FASEB J 27: 1721-1732. CrossRef Medline

Dibner C, Schibler U, Albrecht U (2010) The mammalian circadian timing system: organization and coordination of central and peripheral clocks. Annu Rev Physiol 72:517-549. CrossRef Medline

Golombek DA, Agostino PV, Plano SA, Ferreyra GA (2004) Signaling in the mammalian circadian clock: the NO/cGMP pathway. Neurochem Int 45:929-936. CrossRef Medline

Hastings MH, Maywood ES, O’Neill JS (2008) Cellular circadian pacemaking and the role of cytosolic rhythms. Curr Biol 18:R805-R815. CrossRef Medline

Hoogerwerf WA, Hellmich HL, Cornélissen G, Halberg F, Shahinian VB, Bostwick J, Savidge TC, Cassone VM (2007) Clock gene expression in the murine gastrointestinal tract: endogenous rhythmicity and effects of a feeding regimen. Gastroenterology 133:1250-1260. CrossRef Medline

Kennaway DJ, Owens JA, Voultsios A, Varcoe TJ (2006) Functional central rhythmicity and light entrainment, but not liver and muscle rhythmicity, are clock independent. Am J Physiol Regul Integr Comp Physiol 291: R1172-R1180. CrossRef Medline

Kentish SJ, Wittert GA, Blackshaw LA, Page AJ (2013a) A chronic high fat diet alters the homologous and heterologous control of appetite regulating peptide receptor expression. Peptides 46:150-158. CrossRef Medline

Kentish SJ, O’Donnell TA, Frisby CL, Li H, Wittert GA, Page AJ (2013b) Altered gastric vagal mechanosensitivity in diet-induced obesity persists on return to normal chow and is accompanied by increased food intake. Int J Obes Advance online publication. Retrieved July 30, 2013. doi: 10.1038/ijo.2013.138. CrossRef Medline

Kentish SJ, O'Donnell TA, Isaacs NJ, Young RL, Li H, Harrington AM, Brierley SM, Wittert GA, Blackshaw LA, Page AJ (2013c) Gastric vagal afferent modulation by leptin is influenced by food intake status. J Physiol 591:1921-1934. CrossRef Medline

Kentish S, Li H, Philp LK, O’Donnell TA, Isaacs NJ, Young RL, Wittert GA, Blackshaw LA, Page AJ (2012) Diet-induced adaptation of vagal afferent function. J Physiol 590:209-221. CrossRef Medline

Konturek PC, Brzozowski T, Konturek SJ (2011) Gut clock: implication of circadian rhythms in the gastrointestinal tract. J Physiol Pharmacol 62: 139-150. Medline

Krolczyk G, Zurowski D, Dobrek L, Laskiewicz J, Thor PJ (2001) The role of vagal efferents in regulation of gastric emptying and motility in rats. Folia Med Cracov 42:141-148. Medline

Liu J, Qiao X, Chen JD (2004) Vagal afferent is involved in short-pulse gastric electrical stimulation in rats. Dig Dis Sci 49:729-737. CrossRef Medline

Morioka N, Sugimoto T, Tokuhara M, Nakamura Y, Abe H, Hisaoka K, Dohi T, Nakata Y (2012) Spinal astrocytes contribute to the circadian oscillation of glutamine synthase, cyclooxygenase- 1 and clock genes in the lumbar spinal cord of mice. Neurochem Int 60:817-826. CrossRef Medline

Page AJ, Martin CM, Blackshaw LA (2002) Vagal mechanoreceptors and chemoreceptors in mouse stomach and esophagus. J Neurophysiol 87: 2095-2103. CrossRef Medline

Papka RE, Storey-Workley M, Shughrue PJ, Merchenthaler I, Collins JJ, Usip S, Saunders PT, Shupnik M (2001) Estrogen receptor-alpha and betaimmunoreactivity and mRNA in neurons of sensory and autonomic ganglia and spinal cord. Cell Tissue Res 304:193-214. CrossRef Medline

Pendergast JS, Branecky KL, Yang W, Ellacott KL, Niswender KD, Yamazaki S (2013) High-fat diet acutely affects circadian organisation and eating behavior. Eur J Neurosci 37:1350-1356. CrossRef Medline

Pfaffl MW, Horgan GW, Dempfle L (2002) Relative expression software tool (REST) for group-wise comparison and statistical analysis of relative expression results in real-time PCR. Nucleic Acids Res 30:e36. CrossRef Medline

Rosenwasser AM, Boulos Z, Terman M (1981) Circadian organization of food intake and meal patterns in the rat. Physiol Behav 27:33-39. CrossRef Medline

Schwartz GJ (2000) The role of gastrointestinal vagal afferents in the control of food intake: current prospects. Nutrition 16:866-873. CrossRef Medline

Shinohara K, Funabashi T, Nakamura TJ, Kimura F (2001) Effects of estrogen and progesterone on the expression of connexin-36 mRNA in the suprachiasmatic nucleus of female rats. Neurosci Lett 309:37-40. CrossRef Medline

Stephan FK, Swann JM, Sisk CL (1979) Anticipation of 24 hr feeding schedules in rats with lesions of the suprachiasmatic nucleus. Behav Neural Biol 25:346-363. CrossRef Medline

Trout DL, King SA, Bernstein PA, Halberg F, Cornelissen G (1991) Circadian variation in the gastric-emptying response to eating in rats previously fed once or twice daily. Chronobiol Int 8:14-24. CrossRef Medline

Ueyama T, Krout KE, Nguyen XV, Karpitskiy V, Kollert A, Mettenleiter TC, Loewy AD (1999) Suprachiasmatic nucleus: a central autonomic clock. Nat Neurosci 2:1051-1053. CrossRef Medline

Wang GJ, Tomasi D, Backus W, Wang R, Telang F, Geliebter A, Korner J, Bauman A, Fowler JS, Thanos PK, Volkow ND (2008) Gastric distention activates satiety circuitry in the human brain. Neuroimage 39:1824-1831. CrossRef Medline

Yoo SH, Yamazaki S, Lowrey PL, Shimomura K, Ko CH, Buhr ED, Siepka SM, Hong HK, Oh WJ, Yoo OJ, Menaker M, Takahashi JS (2004) PERIOD2::LUCIFERASE real-time reporting of circadian dynamics reveals persistent circadian oscillations in mouse peripheral tissues. Proc Natl Acad Sci U S A 101:5339-5346. CrossRef Medline 